Michał Jan Filipek

\title{
MIĘDZYNARODOWOPRAWNY STATUS ARCHIPELAGU WYSP ALANDZKICH. KWESTIA DEMILITARYZACJI I NEUTRALIZACJI ALANDÓW
}

Należące do Finlandii Wyspy Alandzkie stanowią archipelag 6000 wysp położonych w środkowej części Morza Bałtyckiego między wybrzeżem Szwecji i Finlandii (w połowie drogi morskiej pomiędzy Sztokholmem a Helsinkami) u wejścia do Zatoki Botnickiej. Wyspy Alandzkie są autonomiczną, zneutralizowaną, zdemilitaryzowaną i w przeważającej części szwedzkojęzyczną prowincją Republiki Finlandii. Blisko 78\% obszaru administracyjnego Alandów stanowi morze (zwane Morzem Alandzkim - szw. Ålands hav, fin. Ahvenanmeri) ${ }^{1}$.

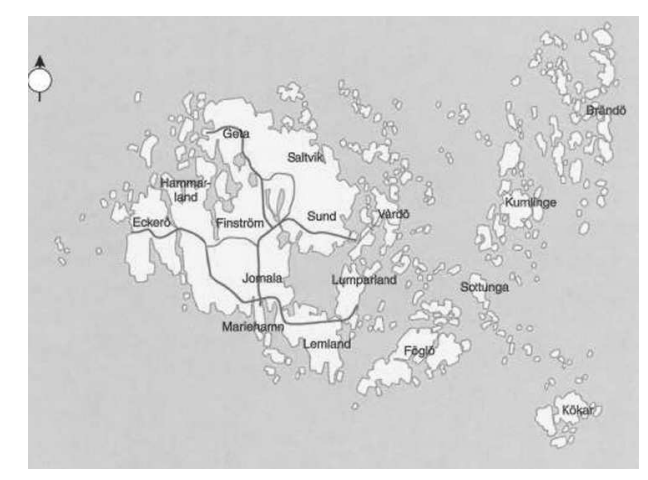

Rysunek 1. Wyspy Alandzkie

Źródło: Åland in Brief, Mariehamn 2008.

1 Międzynarodowe prawo morza na mocy szczególnej konstrukcji reguluje status wód archipelagowych. Artykuł 46 pkt b Konwencji Narodów Zjednoczonych o prawie morza z 1982 r. zdefiniował archipelag jako zespół wysp oraz obszar morski pomiędzy nimi, a także inne naturalne elementy, które pozostają ze sobą w tak ścisłych związkach, że tworzą jedną geograficzną, gospodarzą i polityczną całość, bądź są też historycznie za taką uważane, za: W. Czapliński, A. Wyrozumska, Prawo międzynarodowe publiczne, zagadnienie systemowe, C.H. Beck, Warszawa 2004, s. 152. Konstrukcja ta pozwala zatem postrzegać terytorium archipelagu łącznie z jego wodami terytorialnymi. 


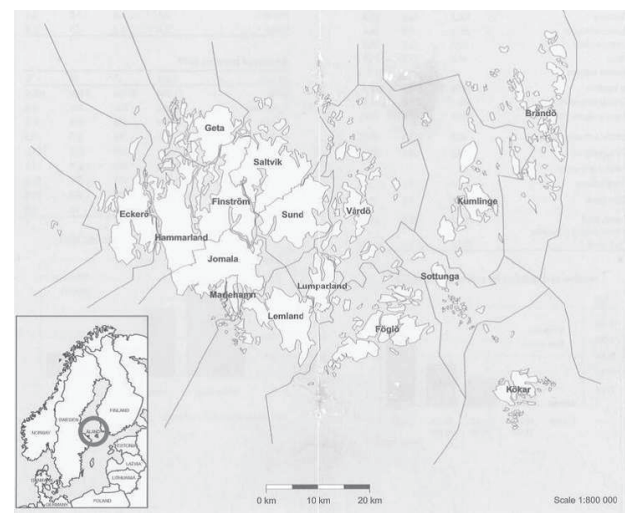

Rysunek 2. Zdemilitaryzowana i zneutralizowana strefa Wysp Alandzkich według konwencji z 1921 roku

Źródło: T. Wulff, Handbok i folkrätt under krig, neutralitet och ockupation, Liber Förlag, Stockholm 1980.

Z archipelagiem Wysp Alandzkich związane są trzy zagadnienia z zakresu prawa międzynarodowego oraz stosunków międzynarodowych: kwestia autonomii, demilitaryzacji oraz neutralizacji regionu archipelagu. Szczególny status archipelagu alandzkiego w prawie międzynarodowym wynika $\mathrm{z}$ jego zdemilitaryzowanego i zneutralizowanego charakteru oraz relatywnie szerokiej politycznej i kulturowej autonomii tego regionu.

Wyspy Alandzkie posiadają status autonomii regulowany zarówno przez akty prawa międzynarodowego, jak również wewnętrzne ustawodawstwo Republiki Finlandii. Najważniejszym aktem prawa krajowego określającym status archipelagu jest Konstytucja Republiki Finlandii z 11 czerwca 1999r. Artykuł 75 Konstytucji przewiduje specjalne ustawodawstwo dla Alandów. Konstytucja wymienia tu dwa akty normatywne: Ustawę o autonomii Wysp Alandzkich ${ }^{2}$ (zwaną dalej również Aktem Autonomii Wysp Alandzkich) oraz Ustawę o prawie własności nieruchomości na Wyspach Alandzkich ${ }^{3}$. Natomiast artykuł 120 Konstytucji stanowi, iż „Wyspy Alandzkie posiadają samorząd zgodnie z tym, co szczegółowo określono w Ustawie o autonomii Wysp Alandzkich"4. Fińska ustawa zasadnicza w artykule 58 pkt 4 stanowi, iż „(...) do kompetencji prezydenta Finlandii należy podejmowanie decyzji w sprawach wskazanych w ustawie o autonomii Wysp Alandzkich, lecz z wyłą-

2 Ang. Act on the Autonomy of Åland, szw. Självstyrelselag för Åland. Por. G. Bonusiak, Statut Wysp Alandzkich, Wyd. Uniwersytetu Rzeszowskiego, Rzeszów 2009.

3 J. Osiński, Konstytucja Finlandii z 1999 roku, Wyd. Sejmowe, Warszawa 2003, s. 90.

4 Ibidem, s. 105. 
czeniem kwestii dotyczących finansów archipelagu”. Uregulowania konstytucyjne wprowadzają zatem konstytucyjną gwarancję istnienia autonomii prowincji. Fakt zamieszczenia $\mathrm{w}$ konstytucji owej gwarancji wraz z postanowieniami zawartymi w aktach prawa międzynarodowego zapewniają wyjątkowo mocną pozycję autonomii alandzkiej.

Długą i bogatą $\mathrm{w}$ wydarzenia historię Alandów można podzielić na trzy okresy: pierwszy - szwedzkie zwierzchnictwo nad Wyspami trwające od 1157 do 1809 r., drugi to rosyjskie zwierzchnictwo trwające od 1809 do 1917 r. oraz trwający od 1917 r. do dnia dzisiejszego okres fińskiej kontroli nad regionem archipelagu alandzkiego. Zmieniający się układ sił w basenie Morza Bałtyckiego nie pozostawał zatem bez wpływu na losy Alandów i ich przynależność administracyjno-państwową.

\section{Uregulowania międzynarodowe dotyczące kwestii demilitaryzacji i neutralizacji regionu}

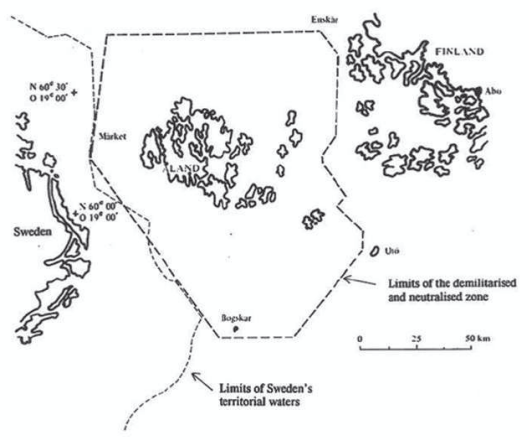

Rysunek 3. Położenie i podział administracyjny Wysp Alandzkich Źródło: Åland in figures 2010, Åsub, Mariehamn 2010.

Zagadnienie neutralizacji oraz demilitaryzacji archipelagu Wysp Alandzkich nie doczekało się do tej pory wyczerpującego opracowania w polskim piśmiennictwie prawniczo-naukowym. Jednakże zagadnienie to może okazać się ze wszech miar interesujące ze względu na specyficzny charakter Alandów, jak również geograficzną bliskość archipelagu. Dodatkowo położenie Wyspy Alandzkich w basenie Morza Bałtyckiego i naturalnie wynikające $\mathrm{z}$ tego członkowstwo archipelagu w społeczności

5 G. Bonusiak, op.cit., s. 36, zob. też: J. Osiński, op.cit, s. 85. 
Regionu Bałtyckiego z pewnością znacząco zwiększa zainteresowanie autonomią alandzką wśród polskich czytelników.

\section{Konwencja o Wyspach Alandzkich z 1856 r.}

Pierwszym aktem prawa międzynarodowego dotyczącym Alandów była konwencja o Wyspach Alandzkich ${ }^{6}$ dołączona do tekstu Traktatu Paryskiego z 30 marca $1856 \mathrm{roku}^{7}$. Stronami owej konwencji były Wielka Brytania, Francja oraz Rosja. Konwencja ta zabraniała prowadzenia jakichkolwiek działań wojennych, fortyfikowania oraz lokowania jakichkolwiek baz wojskowych na terenie archipelagu alandzkiego. Konwencja z $1856 \mathrm{r}$. zawierała również postanowienia o stworzeniu strefy wiecznie zdemilitaryzowanej obejmującej całość terytorium Alandów ${ }^{8}$. Wymieniony akt prawa międzynarodowego, będący następstwem wojny krymskiej, stał się podwaliną przyszłego statusu prawnego Alandów9 . Dokument konwencji, będącej porozumieniem trzech ówczesnych mocarstw, nadawał kwestii alandzkiej wymiar międzynarodowy ${ }^{10}$. Tym samym międzynarodowa opinia publiczna po raz pierwszy zwróciła uwagę na strategicznie położony w basenie Morza Bałtyckiego archipelag alandzki.

Należy przy tym zwrócić uwagę na to, iż konwencja z 1856 r. formalnie nie została nigdy uchylona ${ }^{11}$.

Sytuacja Alandów skomplikowała się jednak po tym, jak w 1917 r. Finlandia odzyskała utraconą niepodległość. Strona szwedzka, która nie była stroną Traktatu Paryskiego, ponownie zaczęła wysuwać roszczenia względem zwierzchnictwa nad archipelagiem alandzkim. Szwecja wysuwała głównie postulaty konieczności ochrony

6 W anglojęzycznej literaturze przedmiotu konwencję o Wyspach Alandzkich z 1856r. często określa się mianem „służebności alandzkiej” (ang. Åland servitude).

7 T. Modeen, Völkerrechtliche Probleme der Aland - Inseln, w: „Zeitschrift für ausländisches öffentliches Recht und Völkerrecht" Vol. 37, 1977, s. 605.

8 L.I. Johansson, The Autonomy of Alland - Background and present situation, w: Islands of Peace. Åland's autonomy, demilitarization and neutralization, red. S. Eriksson, L.I. Johansson, B. Sundback, The Åland Islands Peace Institute, Mariehamn 2006, s. 29-57.

9 Należy zaznaczyć, iż postanowienia konwencji z 1856 r. o zdemilitaryzowanym statusie Alandów, której stroną była również carska Rosja, zostały przez nią kilkukrotnie złamane. Wymienić tu należy rozmieszczenie oddziałów rosyjskich na Wyspach w 1906 r. oraz utworzenie umocnień i obsadzenie ich swoimi oddziałami (liczącymi ponad 6000 żołnierzy) przeprowadzone przez Rosjan w 1916 r. Należy podkreślić, że również Niemcy, Szwedzi oraz obie strony fińskiej wojny domowej dopuściły się naruszenia postanowień tejże konwencji.

${ }^{10}$ E.J. Ruiz, M. Kallonen, Territorial Autonomy and European National Minorities: South Tirol, the Basque Country and the Aland Islands, w: „European Yearbook of Minority Issues” Vol. 2, 2002-2003, s. 249.

${ }^{11}$ C. Scarpulla, The Constitutional Framework for the Autonomy of Aland: A Survey of the Status of an Autonomous Region in the throes of European Integration, Meddelanden från Ålands högskola nr 14, Mariehamn 2002, s. 22. 
języka i kultury szwedzkiej, jednakże dodatkową przesłanką roszczeń było militarnie strategicznie położenie archipelagu.

\section{Akt Autonomii Alandów z 1920 r.}

Sprawa statusu Alandów stanęła na paryskiej konferencji pokojowej w $1918 \mathrm{r}$. Obecna na konferencji delegacja Alandczyków apelowała o uznanie niepodległości regionu. Ostatecznie sprawę przekazano do rozpatrzenia Lidze Narodów. Strona fińska, w obawie przed niekorzystnym werdyktem Ligi, w znamiennym pośpiechu przygotowała Akt Autonomii Alandów, który został uchwalony przez parlament Finlandii 6 maja 1920 r. Dokument ten przewidywał relatywnie szeroką autonomię regionu przejawiającą się $\mathrm{w}$ utworzeniu własnego regionalnego parlamentu oraz rządu. Akt Autonomii Alandów potwierdzał również zdemilitaryzowany charakter Wysp. Nowy dokument nie znalazł jednak poparcia mieszkańców regionu, a sytuacja zaogniła się jeszcze bardziej w momencie aresztowania regionalnych przywódców alandzkich - Juliusa Sundbloma i Carla Björkmana - pod zarzutem zdrady stanu.

\section{Rezolucja Ligi Narodów i konwencja z 1921 r.}

Wydana 24 czerwca 1921 r. rezolucja Ligi Narodów uznała władzę Finlandii nad archipelagiem alandzkim. O przyznaniu Finlandii zwierzchnictwa na Wyspami zdecydował raport komisji specjalnej Ligi Narodów. Dokument ten potwierdzał geograficzną przynależność Wysp do Finlandii, zwracał jednak również uwagę na znaczenie należytego traktowania szwedzkojęzycznych Wyspiarzy przez fińską większość. Rezolucja zaleciła obu stronom sporu wypracowanie kompromisu odnośnie przyszłego statusu Wysp. Zaleceniem rezolucji było również przyjęcie przez obie strony porozumienia szczegółowo regulującego kwestię demilitaryzacji oraz neutralizacji regionu. Obie strony, zarówno fińska, jak i szwedzka, przyjęły rezolucję Ligi Narodów i wkrótce (po upływie 3 dni), tj. 27 czerwca 1921 r., przedłożyły do akceptacji tekst porozumienia. Zawierał on liczne postanowienia, których strona fińska zobowiązała się dotrzymać. Zobowiązania te dotyczyły następujących kwestii:

- zapewnienia na Alandach pierwszoplanowej roli językowi szwedzkiemu,

- zarezerwowania prawa posiadania nieruchomości tylko dla Alandczyków,

- zarezerwowania prawa wyborczego tylko dla stałych mieszkańców archipelagu,

- mianowania gubernatora Alandów przez prezydenta Finlandii jedynie za zgodą przewodniczącego Zgromadzenia Parlamentarnego Alandów,

- zapewnienie nadzoru wykonywania gwarancji zawartych w ugodzie oraz możliwość udzielania konsultacji przez organizację Ligi Narodów. 
Liga Narodów uznała zatem de jure zwierzchnictwo Finlandii nad Wyspami Alandzkimi, nakładając jednocześnie na stronę fińską zobowiązania o charakterze międzynarodowym. Porozumienie pomiędzy Finlandią i Szwecją zostało tym samym zaakceptowane przez Ligę Narodów, a tekst ugody w postaci aneksu dołączono do dokumentu rezolucji z 24 czerwca 1921 r. Decyzja Ligi Narodów nie gwarantowała jedynie ochrony kulturze i językowi szwedzkiemu, potwierdzała ona również postanowienia konwencji z 1856 r. o zakazie wznoszenia fortyfikacji wojskowych w regionie. Kwestia demilitaryzacji i neutralizacji Wysp została rozstrzygnięta dokładniej na podstawie konwencji z 20 października 1921 r., która była bezpośrednim efektem przyjęcia decyzji Ligi.

W pracach nad traktatem, obok przedstawicieli samej Ligi Narodów, brało udział dziesięć państw zainteresowanych bezpieczeństwem narodowym na Bałtyku, w tym: Dania, Estonia, Finlandia, Francja, Łotwa, Niemcy, Polska, Szwecja, Wielka Brytania oraz Włochy. Opracowana konwencja skierowana została do ratyfikacji przez parlamenty wyżej wymienionych państw ${ }^{12}$. Jedynym państwem posiadającym dostęp do Morza Bałtyckiego, a niebędącym stroną konwencji, był nieuznawany wówczas (od rewolucji październikowej) przez państwa zachodnie Związek Radziecki ${ }^{13}$. Dlatego też, po jego przystąpieniu do Ligi Narodów w 1934 r., strona radziecka prezentowała stanowisko, iż nie jest związana postanowieniami konwencji z $1921 \mathrm{roku}^{14}$.

\section{Postanowienia konwencji z 1921 r.}

Konwencja o demilitaryzacji i neutralizacji Alandów z 1921 r. nie unieważniała postanowień konwencji z 1856 r., a jedynie w dużej mierze precyzowała je i rozwijała. Konwencja zabraniała umieszczania na Wyspach umocnień i baz wojskowych, jak również przemieszczania przez Wyspy oddziałów, broni oraz materiałów o znaczeniu militarnym ${ }^{15}$. Zakazem objęto ponadto wyrób, wwóz oraz tranzyt broni oraz materiałów wybuchowych. Finlandia została zatem zobowiązana do przeprowadzenia całkowitej demilitaryzacji regionu, rozumianej jako ograniczonego wykonywania

$12 \mathrm{~W}$ Polsce konwencja ta została ratyfikowana na mocy Ustawy w przedmiocie ratyfikacji konwencji dotyczących niefortyfikowania i zneutralizowania Wysp Alandzkich, podpisanej w Genewie w dniu 20 października 1921 roku, rekomendowanej przez Komisję Spraw Zagranicznych. Ustawa ta została przyjęta na posiedzeniu Sejmu Ustawodawczego 18 maja 1922 r. bez żadnych głosów sprzeciwu.

13 Obok Związku Radzieckiego, również Litwa nie była stroną konwencji z 1921 r., należy jednak pamiętać, że w tamtym okresie państwo to nie posiadało wybrzeża bałtyckiego.

14 Postanowienia konwencji z 1856 r. były dla carskiej Rosji, jako państwa sprawującego zwierzchnictwo nad Alandami, w dużym stopniu niewygodne z uwagi na strategiczne położenie Wysp.

15 G. Bonusiak, op.cit., s. 31. 
zwierzchnictwa terytorialnego nad Wyspami ${ }^{16}$. Jednocześnie wprowadzono regulacje mające na celu wyznaczenie obszaru zdemilitaryzowanego. Przyjęto również, że strefa zdemilitaryzowana obejmuje teren wszystkich wysp i wysepek archipelagu alandzkiego geograficznie należących do Alandów oraz wody w promieniu trzech mil morskich od ich brzegów ${ }^{17}$. Granice strefy zdemilitaryzowanej oraz wód terytorialnych Szwecji i Finlandii przebiegają w przybliżeniu szlakiem żeglugowym przez Morze Alandzkie oraz Kwarken Południowy ${ }^{18}$.

Konwencja z 1921 r. zawierała również regulację odnośnie neutralizacji prowincji w wypadku działań zbrojnych w regionie ${ }^{19}$. Znana w nauce prawa międzynarodowego regulacja neutralizacji na drodze umowy międzynarodowej wyłączała terytorium archipelagu alandzkiego z teatru działań wojennych oraz wykorzystywania go do jakichkolwiek działań militarnych ${ }^{20}$. Neutralizację na mocy wyżej wymienionej konwencji z 1921 r. należy uznać jako neutralizację wojskową (inaczej: neutralizacja obszaru) dotyczącą całości terenu archipelagu alandzkiego, polegającą na zakazie wykorzystywania terytorium Wysp Alandzkich do przygotowywania działań wojennych, a zwłaszcza ich prowadzenia ${ }^{21}$.

${ }^{16} \mathrm{~W}$ nauce prawa międzynarodowego poprzez instytucję „demilitaryzacji” rozumie się umowny akt prawa międzynarodowego nakładający na państwo obowiązek nieutrzymywania na określonej części jego terytorium baz wojskowych, fortyfikacji i sił zbrojnych lub nakazujący zburzenie istniejących już fortyfikacji i wycofanie wojsk przebywających na tym terenie, za: J. Białocerkiewicz, Prawo międzynarodowe publiczne, Wyd. Uniwersytetu Warmińsko-Mazurskiego, Olsztyn 2005, s. 227. Należy zatem uznać, iż konwencja z $1921 \mathrm{r}$. jako pierwsza wprowadzała całkowitą demilitaryzację regionu archipelagu alandzkiego. Warto również zwrócić uwagę na definicję „demilitaryzacji” proponowaną przez J. Salomona w Dictionnaire de droit international public, Bruylant, Bruxelles 2001, według której „demilitaryzacja” to środki zakazujące obecności sił zbrojnych i baz wojskowych oraz wykonywania jakichkolwiek testów broni oraz ćwiczeń czy manewrów na określonym geograficznie terenie. Konstrukcja demilitaryzacji może mieć charakter całkowity bądź częściowy.

17 G. Bonusiak, op.cit., s. 31.

18 D.R. Bugajski, Prawa żeglugowe okrętu w świetle prawa międzynarodowego, Wyd. Nauk. Scholar, Warszawa 2009, s. 253.

${ }^{19}$ Konwencja z 1921 r. przewidywała również kilka wyjątków od zasady neutralności regionu archipelagu alandzkiego: w przypadku zbrojnego konfliktu na terenie Morza Bałtyckiego Finlandia zachowała prawo do podejmowania wszystkich niezbędnych kroków, których celem będzie zachowanie neutralności prowincji. Również w przypadku zbrojnej napaści na Alandy, Finlandia zachowała prawo do podjęcia wszelkich niezbędnych kroków, których celem będzie odparcie ataku agresora do czasu interwencji jednego z sygnatariuszy tejże konwencji.

${ }^{20}$ Wydaje się, iż należy uznać za zasadne stwierdzenie L. Mariona, że neutralizacja jest konstrukcją odnoszącą się zarówno do regulacji prawnych, jak również do strategii dyplomatycznej. Szerzej zob. M. Chillaud, Territorial Disarmament in Northern Europe The Epilogue of a Success Story?, Stockholm International Peace Research Institute Policy Paper No. 13, 2006, s. 8.

${ }^{21}$ Wydaje się więc zasadne podkreślenie rozróżnienia konstrukcji neutralizacji oraz neutralności na gruncie prawa międzynarodowego. Instytucja neutralności odnosi się bowiem do przyjęcia postawy bądź deklaracji konstruującej neutralny status danego międzynarodowego podmiotu prawnego, jakim jest państwo. Konstrukcja neutralności zwykle odnosi się do całości terytorium danego państwa, podczas gdy instytucja neutralizacji obejmuje najczęściej jego ograniczoną, wydzieloną strefę. Neutralność jest koncepcją polityki prowadzonej przez państwo bądź przez grupę państw mającą na celu uniknięcie pewnych konsekwencji 
Konwencja ta była zatem umową międzynarodową łączącą demilitaryzację z neutralizacją regionu w celu eliminacji negatywnych skutków stacjonowania garnizonów na terytorium Alandów. Jest jednak kilka wyjątków od przyjętych w konwencji postanowień: jednostki marynarki mają prawo do nieszkodliwego przepływu przez zdemilitaryzowaną strefę Wysp, a strona fińska ma prawo do udzielenia pozwolenia czasowego postoju obcych jednostek pływających na wodach prowincji (z wyłączeniem okrętów podwodnych). Zgodnie z postanowieniami konwencji z 1921 r. strona fińska ma również prawo do wysłania sił zbrojnych w celu zapewniania bądź przywrócenia w regionie porządku publicznego (art. 4). W wypadku zbrojnego konfliktu w basenie Morza Bałtyckiego, konwencja przyznaje stronie fińskiej możliwość czasowego podłożenia min morskich na wodach terytorialnych strefy zdemilitaryzowanej. W przypadku zbrojnej napaści i zagrożenia neutralności Wysp Alandzkich, strona fińska uprawniona jest do podjęcia kroków i środków koniecznych w celu odparcia agresora. Strona fińska uprawniona jest do obrony Wysp do chwili interwencji zbrojnej innych państw (art. 7).

Ciekawą regulację stanowi art. 7 pkt 2 konwencji z 1921 r. przewidujący kolektywną obronę Alandów prowadzoną przez inne państwa. Konwencja nie wymienia tu zastrzeżenia, iż państwami podejmującymi interwencję zbrojną w celu obrony neutralności Wysp mogą być jedynie jej strony. Równie interesującą regulację stanowi art. 8 uznający, iż postanowienia konwencji pozostają w mocy niezależnie od zmian status quo w basenie Morza Bałtyckiego („,denna konventions bestämmelser skall förbli i kraft, vilka de förändringar än må vara som kan inträda uti det nuvarande status quo i Östersjön”) ${ }^{22}$. Trzeba również wspomnieć, iż w tekście konwencji z 1921 r. nie ma żadnych regulacji odnoszących się expressis verbis do przestrzeni powietrznej Wysp Alandzkich. Na podstawie art. 4 konwencji z 1921 r. ${ }^{23}$ należy

w związku z prowadzonymi działaniami wojennymi, natomiast konstrukcja neutralizacji jest koncepcją mającą zastosowanie zarówno podczas konfliktu zbrojnego, jak i w czasie pokoju. Tym samym konwencja haska V z 18 października 1907 r., odnośnie praw i obowiązków mocarstw neutralnych, nie wyraża sensu i znaczenia konstrukcji neutralizacji.

W świetle powyższego należy uznać, iż obie konstrukcje różnią się od siebie w znaczący sposób i nie należy ich w żaden sposób traktować ekwiwalentnie. Warto również w tym kontekście zwrócić uwagę, iż Finlandia (podobnie jak i Szwecja) określana jest jako państwo neutralne, choć sama strona fińska używa obecnie częściej określenia „niezrzeszony”, „niezaangażowany” (non-aligned). Niemniej jednak koncepcja neutralności jest podstawowym postulatem polityki zagranicznej Finlandii. Należy jednak podkreślić, iź samo prowadzenie przez państwo polityki zagranicznej opartej na zasadzie neutralności nie jest tożsame z posiadaniem statusu państwa trwale (wieczyście) neutralnego. Fińska „doktryna neutralności” polityki zagranicznej wyraża się w zachowaniu wolności wyboru własnego stanowiska (w razie wybuchu konfliktu zbrojnego) bez obowiązku opowiedzenia się po jednej ze stron konfliktu. Szerzej zob. M. Chillaud, op.cit., s. 8.

22 Internationella avtal och dokument rörande Åland 1856-1992, Ålands kulturstiftelse, Mariehamn 1993.

23 Artykuł 4 konwencji z 1921 r. wyraża zakaz wchodzenia wszelkich samolotów wojskowych w zdemilitaryzowaną strefę Alandów. Przelot bez możliwości lądowania dozwolony jest jedynie samolotom wojskowym wchodzących w skład Fińskich Sił Powietrznych. 
jednak przyjąć, iż przestrzeń powietrzna nad Wyspami również należy do strefy zdemilitaryzowanej ${ }^{24}$.

Po zakończeniu „wojny zimowej”25, 11 października 1940 r. został podpisana dwustronna umowa między Finlandią i Związkiem Radzieckim. W umowie tej strona fińska zobowiązała się do przeprowadzenia demilitaryzacji prowincji. Finlandia na podstawie umowy zobowiązana była również do niefortyfikowania i nieumacniania Wysp w przyszłości. Stronie radzieckiej przyznane zostało prawo utworzenia konsulatu w prowincji w celu sprawowania nadzoru nad realizacją zobowiązań spoczywających na stronie fińskiej. Umowa przywracała zatem status archipelagu określony w konwencjach z lat 1856 i 1921.

Po zakończeniu działań wojennych II wojny światowej kwestia zdemilitaryzowanego statusu quo prowincji powróciła na arenę międzynarodową. Podpisany 10 lutego 1947 r. w Paryżu układ pokojowy (tzw. pokój paryski) pomiędzy sojusznikami III Rzeszy a aliantami potwierdzał zdemilitaryzowany status Wysp Alandzkich. W przypadku Finlandii art. 5 tego układu stanowił, iż: „Wyspy Alandzkie powinny pozostać zdemilitaryzowane zgodnie z dzisiejszą sytuacją”.

\section{Wątpliwości odnośnie obowiązywania konwencji z 1921 r.}

W okresie powojennym pojawiły się wątpliwości odnośnie obowiązywania konwencji z 1921 r. Sugerowano, że w związku z faktem, iż Organizacja Narodów Zjednoczonych nie przejęła zobowiązań gwarancyjnych Ligi Narodów (po jej rozwiązaniu), zakładany w konwencji z 1921 r. system gwarancji stracił na aktualności. Dodatkowo dowodzono, że mimo faktu, iż konwencja z 1921 r. nie została nigdy formalnie uchylona, można na postawie zasady desuetudo (z faktu niestosowania umowy przez długi okres czasu $)^{26}$ uznać ją za nieobowiązującąc ${ }^{27}$. Poza wątpliwościami i rozważaniami doktrynalnymi również zmiany geopolityczne, które nastąpiły w basenie Morza Bałtyckiego po przyjęciu konwencji, a więc po 1921 r., mogły zrodzić pytanie

${ }_{24}$ M. Koskenniemi, M. Lehto, Finland and the Law of the Sea, w: The Law of the Sea: The European Union and its Member States, red. T. Treves, Kluwer Law International, The Hague 1997, s. 148.

${ }^{25}$ Podczas radziecko-fińskiej „wojny zimowej” w latach 1939-1940 strona fińska rozmieściła niewielką liczbę oddziałów na terenie prowincji. Finowie utworzyli również obronę przeciwdesantową i zainstalowali szereg baterii artylerii nadbrzeżnej. Strona fińska ponownie złamała postanowienia o neutralizacji i demilitaryzacji Alandów w czerwcu 1941 r. po rozpoczęciu „wojny kontynuacyjnej”, zob. K. Kubiak, Nordyckie terytoria autonomiczne, w: „Sprawy Międzynarodowe” 2002, nr 4. s. 88.

26 W. Czapliński, A. Wyrozumska, Prawo międzynarodowe..., op.cit., s. 506.

27 Zob. B.E. Castren, Die Entmilitarisierung und Neutralisierung der Åland - Inseln, w: Völkerrecht und rechtliches Weltbild, Festschrift für Alfred Verdross, Springer, Berlin 1960, s. 115-116 oraz T. Modeen, Völkerrechtliche Probleme der Åland - Inseln, w: „Zeitschrift für ausländisches öffentliches Recht und Völkerrecht" Vol. 37, 1977, s. 606-619. 
odnośnie możliwości uznania konwencji z 1921 r. za nieobowiązującą na podstawie znanej w prawie międzynarodowym zasady-zastrzeżenia rebus sic stantibus (art. 62 Konwencji wiedeńskiej o prawie traktatów z 22 maja 1969 r.). Zwracano również uwagę na fakt nierespektowania statusu Wysp przez strony konfliktu podczas działań wojennych II wojny światowej. Dodatkowych wątpliwości przysparzał fakt, iż kilka państw położonych w bliskim sąsiedztwie Finlandii nie jest stronami konwencjii ${ }^{28}$.

Należy jednak podkreślić, iż przeważająca część doktryny wyraża pogląd, że mimo znaczących zmian uwarunkowań geopolitycznych konwencja z $1921 \mathrm{r}$. nadal pozostaje w mocy ${ }^{29}$. Kilku autorów ${ }^{30}$ wskazywało na potwierdzenie międzynarodowego statusu Alandów poprzez konstruowane przez prawo międzynarodowe instytucje permanent settlement oraz objective regime, które - nakładając zobowiązania na państwa - uznają tym samym, że pewien stan faktyczny stał się już prawem zwyczajowym w europejskim systemie prawa ${ }^{31}$. Należy zatem uznać, iż poza wszelką wątpliwością zarówno konwencja z 1921 r., jak również dwustronna umowa pomiędzy Finlandią i Związkiem Radzieckim z 1940 r. oraz pokój paryski z 1947 r. nadal w pełni zachowują moc prawną.

Ponadto aktem prawa międzynarodowego odnoszącym się do kwestii terytoriów zdemilitaryzowanych jest Protokół dodatkowy do konwencji genewskich z dnia 12 sierpnia 1949 r., dotyczący ochrony ofiar międzynarodowych konfliktów zbrojnych (Protokół I). Artykuł 60 pkt 1 tegoż protokołu stanowi, iż: „nie wolno stronom konfliktu rozszerzać swych operacji wojskowych na strefy, którym w drodze porozumienia nadany został status strefy zdemilitaryzowanej, jeżeli takie rozszerzenie jest sprzeczne z postanowieniami takiego porozumienia". Natomiast artykuł 60 pkt 6 protokołu stanowi, iż: „jeżeli walki zbliżają się do strefy zdemilitaryzowanej i jeżeli strony zawarły w tej sprawie porozumienie, żadna $\mathrm{z}$ nich nie będzie mogła wykorzystywać takiej strefy do celów związanych z prowadzeniem operacji wojskowych ani jednostronnie uchylić jej statusu”.

Kwestia międzynarodowego statusu Alandów powróciła ponownie na arenę międzynarodową w momencie złożenia przez Finlandię w 1992 r. wniosku akcesyjnego do Unii Europejskiej. Wtedy to Komisja Unii Europejskiej potwierdziła zdemilitaryzowany status archipelagu alandzkiego, a żadne państwo członkowskie Unii nie

28 Stronami konwencji z 1921 r. nie są: Rosja, Litwa oraz Norwegia. Należy jednakże zwrócić uwagę, iż do tej pory (2010 r.) żadne państwo Regionu Bałtyckiego nie kwestionowało i nie poddawało w wątpliwość zdemilitaryzowanego i zneutralizowanego statusu Alanadów.

${ }^{29}$ L. Hannikainen, The continued validity of the demilitarised and neutralised status of the Aland Island, w: „Zeitschrift für ausländisches öffentliches Recht und Völkerrecht” Vol. 54, 1994, s. 614-651.

30 Między innymi: E. Klein, N. Fagerlund, M. Lehto, A.D. McNair.

31 T. Tiilikainen, Aland in European security policy, w: The Nordic countries and the European Security and Defence Policy, red. J.K. Bailes, G. Herolf, B. Sundelius, Stockholm International Peace Research Institute, Sztokholm 2006, s. 349-355. 
zakwestionowało tej opinii ${ }^{32}$. Protokół nr 2, zwanym również Protokołem Alandzkim, będący aneksem do traktatu akcesyjnego Finlandii do Unii Europejskiej, uznaje w preambule szczególny status Alandów w prawie międzynarodowym.

Z pewnością kwestia demilitaryzacji i denaturalizacji regionu wróciłaby w kontekście ewentualnego przystąpienia Finlandii do struktury Organizacji Paktu Północnoatlantyckiego ${ }^{33}$. Wydaje się, że w takiej sytuacji mogłaby zostać podjęta próba wypowiedzenia konwencji 1921 r., a w efekcie czego zniesienie zdemilitaryzowanego i zneutralizowanego statusu Alandów. Wydaje się również, iż nie ma żadnych przeszkód natury prawnej do wypowiedzenia konwencji z 1921 r. przez państwa będące jej sygnatariuszami, które (za wyjątkiem Finlandii i Szwecji) są jednocześnie członkami Organizacji Traktatu Północnoatlantyckiego. Jeśli natomiast Finlandia przystąpiłaby do struktury NATO bez uprzedniej zmiany statusu Alandów nie byłby to wcale precedens na arenie międzynarodowej. Znany jest bowiem casus archipelagu Svalbard, znajdującego się pod norweskim zwierzchnictwem, który zachował swój zdemilitaryzowany charakter mimo faktu przystąpienia Norwegii w 1949 r. do struktury NATO. Wykazać można pewne podobieństwo obu przypadków. Demilitaryzacja archipelagu Svalbard ${ }^{34}$, podobnie jak demilitaryzacja Alandów, opiera się na porozumieniach międzynarodowych. Podobieństwo obu przypadków wynika również z faktu bliskiego sąsiedztwa z Rosją, która była w przeszłości i zdaje się nadal być zainteresowana oboma regionami w aspekcie zarówno politycznym, jak i militarnostrategicznym. Jako kolejny przykład posłużyć mogą należące do Grecji (będącej od 1952 r. członkiem NATO) zdemilitaryzowane wyspy: Korfu, Paxoi, Chios, Lesbos, Lemnos, Nikaria oraz wyspa Samos.

Z kwestią przystąpienia Finlandii, a w efekcie również i Wysp Alandzkich, do struktury NATO związane jest pewnego rodzaju uzależnienie od reakcji Kremla. Rząd alandzki prezentuje natomiast stanowisko, iż ewentualne przystąpienie

32 E. Hannikainen, op.cit., s. 624.

${ }^{33}$ O takiej możliwości po wydarzeniach w Gruzji w 2008 r. mówił w wywiadzie dla austriackiego dziennika „Die Presse” fiński minister spraw zagranicznych, Alexander Stubb. Szerzej zob. też: S. Moćkun, Perspektywy potencjalnego przystapienia Szwecji i Finlandii do Nato, w: „Bezpieczeństwo Narodowe” nr 11, marzec 2009, s. 79-80.

${ }^{34}$ Demilitaryzacja archipelagu Svalbard opiera się na podpisanym 9 lutego 1920 r. w Paryżu Traktacie Spitsbergeńskim. Artykuł 9 tegoż traktatu stanowi, iż: „z zastrzeżeniem praw i obowiązków, mogących wyniknąć dla Norwegii z jej przystąpienia do Ligi Narodów, Norwegia obowiązuje się nie zakładać i nie pozwolić na utworzenie żadnej bazy morskiej na obszarach, wskazanych w art. 1., nie budować żadnych fortyfikacji w tych obszarach, które nie mogą nigdy być używane dla celów wojennych". Mimo iż Traktat Spitsbergeński nie posługuje się terminem „demilitaryzacja”, jego postanowienia o niefortyfikowaniu obszaru są uznawane za porównywalne z postanowieniami konwencji z 1921 r. Po wejściu Norwegii do struktury NATO postanowienia Traktatu Spitsbergeńskiego nie zostały nigdy naruszone, zob. T. Tiilikainen, Åland in European..., op.cit. s. 353. 
Finlandii do struktury Paktu Północnoatlantyckiego nie wpłynie w żaden sposób na kwestie zdemilitaryzowanego statusu Wysp ${ }^{35}$.

Zgodnie z art. 12 Aktu Autonomii Wysp Alandzkich, w związku ze zdemilitaryzowanym i zneutralizowanym charakterem archipelagu, osoby posiadające alandzkie prawo domicylu, które zamieszkały na Alandach przed ukończeniem 12 roku życia, zwolnione są z obowiązku odbywania służby wojskowej ${ }^{36}$.

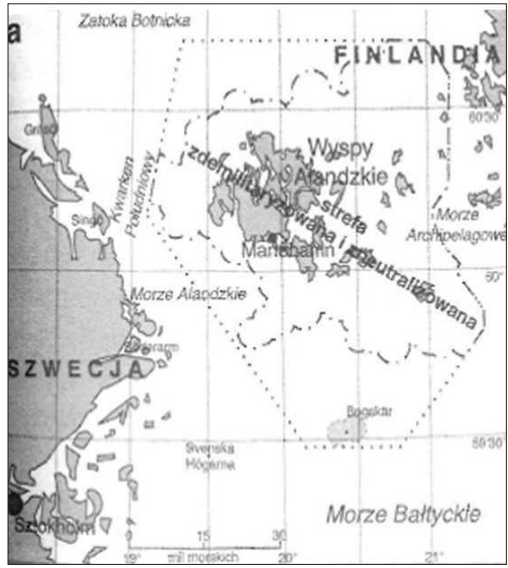

Rysunek 4a. Strefa zdemilitaryzowana i zneutralizowana

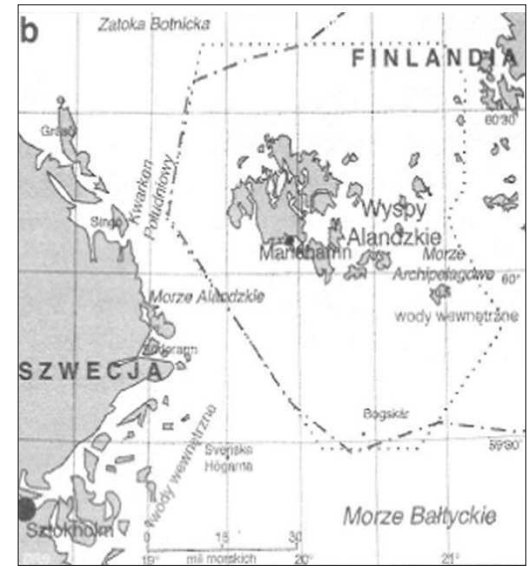

Rysunek 4b. Granica morza terytorialnego Finlandii

Źródło: D.R. Bugajski, Prawa żeglugowe okrętu w świetle prawa międzynarodowego, Wyd. Nauk. Scholar, Warszawa 2009.

\section{Wyspy Alandzkie na arenie międzynarodowej. Członkowstwo w organizacjach międzynarodowych}

Pozycja międzynarodowa Finlandii, a w skutek czego również i podległej jej prowincji Wysp Alandzkich, uwarunkowana była w okresie powojennym stosunkowo mocnym polityczno-gospodarczym uzależnieniem od Związku Radzieckiego. Uzależnienie to wpływało $\mathrm{w}$ dużym stopniu na prowadzenie w pełni suwerennej polityki zagranicznej. Konieczność konstruowania polityki zagranicznej z uwzględnieniem interesów sąsiedniego mocarstwa skutkowała opóźnionym, w stosunku do reszty

35 T. Tiilikainen, op.cit., s. 355.

36 Wspomniany artykuł 12. Aktu Autonomii przewiduje możliwość odbycia służby zastępczej. 
państw Północy, włączeniem się Finlandii w procesy integracyjne zmierzające do budowania ładu i bezpieczeństwa międzynarodowego ${ }^{37}$.

Po odrzuceniu polityki nieformalnego uzależnienia od Związku Radzieckiego, strona fińska podjęła szereg kroków celem szybkiego zbliżenia z zachodnimi strukturami organizacji międzynarodowych. Rozpad Związku Radzieckiego oraz Jesień Narodów 1989 r. wytworzyły nową jakościowo sytuację polityczną dla Finlandii ${ }^{38}$. Wysiłki i aspiracje Finów do aktywniejszej działalności na arenie międzynarodowej podkreślone zostały poprzez fakt uzyskania przez Finlandię pełnego członkostwa w Radzie Europy w 1989 r. Również złożenie wniosku akcesyjnego do Wspólnot Europejskich w 1992 r. przez rząd fiński wskazywało na wyraźną tendencję zacieśniania kontaktów Finlandii z państwami zachodnimi.

Wiadomo, że Finlandia niejako zmuszona była (i nadal jest) do uwzględniania w swej polityce zagranicznej autonomicznego statusu Wysp Alandzkich. We wszystkich relacjach międzynarodowych, w których stroną jest rząd fiński, a które mogą mieć jakikolwiek wpływ na Alandy, uczestniczy również przedstawiciel Wysp ${ }^{39}$. Jeżeli umowa międzynarodowa zawarta przez Finlandię jest sprzeczna z Aktem Autonomii Wysp Alandzkich, to umowa ta nie wchodzi w życie na terenie Alandów. Autonomiczny status Wysp umożliwił prowincji samodzielne decydowanie odnośnie akcesji do Unii Europejskiej. M. Sobczyński słusznie zauważa podobieństwo tej sytuacji do casusu, kiedy to do Wspólnoty przystępowała Dania sprawująca zwierzchnictwo nad autonomicznymi terytoriami - Grenlandii i Wysp Owczych ${ }^{40}$.

Na początku lat 90. XX stulecia zaczęto wskazywać na możliwość wystąpienia trudności połączenia alandzkiej autonomii z jednej strony z zasadami integracji ekonomicznej państw zachodnich w ramach zinstytucjonalizowanej międzynarodowej organizacji z drugiej strony. Jednolity Akt Europejski z 1986 r. wprowadzał nowe cele - stworzenie wspólnego rynku bez wewnętrznych granic, w obrębie którego wszelkie dobra, kapitał oraz ludzie mogliby przemieszczać się bez żadnych przeszkód. Uznawano, iż cel ten, a zwłaszcza prawo do prowadzenia działalności handlowej oraz prawo do nabywania nieruchomości, nie może iść $\mathrm{w}$ parze $\mathrm{z}$ ograniczeniami

37 G. Bonusiak, op.cit., s. 35 .

38 J. Osiński, op.cit., s. 17.

${ }^{39}$ M. Sobczyński, Rola i miejsce Wysp Alandzkich w Unii Europejskiej, w: Małe państwa Europy Zachodniej i terytoria o statusie specjalnym. Ich rola i miejsce w Unii Europejskiej, red. R. Żelichowski, Instytut Studiów Politycznych PAN, Warszawa 2008, s. 121-145.

40 Parlament Wysp Owczych (Lagting) w styczniu 1974 r., w obawie o przyszłość rybołówstwa będącego podstawą farerskiej gospodarki, podjął decyzję o pozostaniu prowincji poza Wspólnotą Europejską. Grenlandia przystąpiła natomiast wraz z Danią do Wspólnoty w 1973 r., jednakże po 12 latach członkowstwa w organizacji, na mocy lokalnego referendum, mieszkańcy wyspy zdecydowali o opuszczeniu Wspólnoty. Zarówno Grenlandia, jak również Wyspy Owcze (w przeciwieństwie do Alandów) pozostają poza Układem z Schengen. 
wynikającymi z obowiązującego na Wyspach Alandzkich prawa domicylu. Podkreślano również, że ewentualna akcesja Alandów do Wspólnot Europejskich, bez uprzedniej derogacji przepisów dotyczących prawa domicylu, kolidowałaby z ustawodawstwem wspólnotowym. W zaistniałej sytuacji Alandczycy stanęli przed wyborem dwóch różnych strategii wobec Wspólnot Europejskich i późniejszej Unii Europejskiej. Z jednej strony rysowała się możliwość pełnej partycypacji w procesie kooperacyjno-integracyjnym zachodzącym na arenie międzynarodowej, z drugiej strony istniała opcja braku wyrażenia jakichkolwiek aspiracji członkowskich w europejskich strukturach międzynarodowych - śladem duńskich terytoriów autonomicznych (Grenlandii i Wysp Owczych). Jasnym dla Alandczyków stał się fakt konieczności prowadzenia negocjacji celem uzyskania szczególnej, uprzywilejowanej pozycji pozwalającej na utrzymanie alandzkiego prawa do domicylu.

\section{Alandy na drodze do Unii Europejskiej}

W 1992 r. parlament alandzki (Lagting) przyjął porozumienie o utworzeniu Europejskiego Obszaru Gospodarczego. Przyjęcie tego porozumienia stało się w pewnym sensie wyznacznikiem kierunku przyszłego statusu Wysp w późniejszej Unii Europejskiej. Decyzja Finlandii o przystąpieniu do struktur Unii Europejskiej miała znaczący wpływ na kwestię autonomii Wysp Alandzkich. Zgodnie z postanowieniami Aktu Autonomii Wysp Alandzkich, zawierane porozumienia i umowy międzynarodowe dotyczące kwestii pozostających w kompetencjach Alandczyków muszą uzyskać aprobatę parlamentu alandzkiego (art. 59 Aktu Autonomii). Umowa akcesyjna Finlandii oraz Unii Europejskiej stały się zatem przedmiotem decyzji parlamentu alandzkiego. W zaistniałej sytuacji celem rządu fińskiego stało się zapewnie jak najszerszej gwarancji autonomii Wyspom Alandzkim oraz zachowanie alandzkiej regulacji prawa domicylu. Naczelną kwestią było zapewnienie ciągłości alandzkiego prawa domicylu po wstąpieniu Finlandii do Unii Europejskiej. Istotną kwestią była również polityka fiskalna. Podstawowym powodem dążeń strony fińskiej do wyłączenia Alandów z obowiązku harmonizacji podatków było widmo zniesienia wszelkiej sprzedaży wolnocłowej na terenie Unii Europejskiej, co miałoby znaczący wpływ na sytuację finansowo-ekonomiczną Alandów. Przeprowadzane badania wykazały, iż w przypadku zniesienia sprzedaży wolnocłowej, prowadzonej na promach i statkach turystycznych na trasach łączących Wyspy Alandzkie ze Szwecją oraz Finlandią, wpływy Alandczyków zmalałyby o więcej niż $50 \%{ }^{41}$. Spadek dochodów z wolnocłowej

${ }^{41}$ Åland in the European Union, Europe Information, Ministry for Foreign Affairs of Finland, Helsinki 2005, s. 19. 
sprzedaży na promach i statkach turystycznych mógłby w znaczący sposób wpłynąć na turystykę będącą jedną z podstawowych gałęzi gospodarki Alandów.

Podczas negocjacji z Unią rząd fiński przedstawił projekt statusu Wysp w Unii, będący bazą w prowadzonych negocjacjach. Na sesji Rady Unii Europejskiej w Brukseli 22 lutego 1994 r., dotyczącej przystąpienia Finlandii do Wspólnoty, przedstawiciele rządu fińskiego przyjęli ostatecznie stanowisko Unii w sprawie Alandów. Traktat akcesyjny dotyczący przystąpienia Republiki Finlandii do Unii Europejskiej został podpisany na greckiej wyspie Korfu 24 czerwca 1994 r. Unia Europejska przyjęła wszystkie warunki odnośnie Wysp Alandzkich wysuwane przez rząd fiński w czasie prowadzonych negocjacji akcesyjnych. Było to pewne odstępstwo od ogólnie przyjętej normy dostosowywania przez państwo zabiegające o członkowstwo we Wspólnocie wszelkich regulacji legislacyjny do norm unijnych ${ }^{42}$.

Najważniejsze postanowienia dotyczące Wysp Alandzkich zawarte zostały w specjalnym protokole - Protokole nr 2 zwanym również Protokołem Alandzkim - będącym aneksem do Traktatu akcesyjnego Finlandii do Unii Europejskiej. Protokół Alandzki uznaje szczególny status Alandów w prawie międzynarodowym oraz wymienia pewne ograniczenia stosowania ustawodawstwa unijnego. Protokół potwierdza ograniczenia wynikające $\mathrm{z}$ alandzkiego prawa domicylu (art. 1 pkt 1) oraz wprowadza ograniczenia w swobodzie prowadzenia działalności gospodarczej (art. 1 pkt 2). Protokół potwierdził również wyłączenie Wysp z unijnej polityki fiskalnej, uznając je za tzw. „terytorium trzecie” w kategorii harmonizacji unijnych podatków pośrednich, tym samym uznając, iż prowincja nie ma obowiązku dostosowywania polityki fiskalnej do wzorców unijnych (art. 2). Uregulowania zawarte w Traktacie akcesyjnym nie mogą być zmieniane przez dyrektywy bądź rezolucje unijne, ale jedynie przez wspólną akceptację wszystkich państw członkowskich.

\section{Wyspy Alandzkie we Wspólnocie}

Wynik negocjacji odebrany został jako sukces Alandczyków, a oficjalne uznanie w Protokole Alandzkim szczególnego statusu Alandów w prawie międzynarodowym w istocie potwierdziło autonomiczny, zdemilitaryzowany oraz zneutralizowany charakter prowincji na arenie międzynarodowej. Ostatecznie negocjacje członkowskie Finlandii zostały zakończone 1 marca 1994 r. Traktat akcesyjny zawarty przez Finlandię poddano referendum o zasięgu ogólnokrajowym ${ }^{43}$. W końcowej fazie należało

\footnotetext{
42 Aland in the European Union, op.cit., s. 20.

43 W ogólnokrajowym referendum odnośnie przystąpienia do Unii Europejskiej, które odbyło się 16 października 1994 r., blisko 52\% Alandczyków wypowiedziało się za członkowstwem w unijnej strukturze organizacyjnej. Przeciw wstąpieniu do Unii Europejskiej było 48\% mieszkańców prowincji. W oddzielnym
} 
jeszcze dostosować Akt Autonomii Wysp Alandzkich do Traktatu akcesyjnego. Uzupełnienie dokumentu Aktu Autonomii nastąpiło 31 grudnia 1994 r. Do dokumentu dołączono rozdział 9 a, zawierający uregulowania dotyczące Unii Europejskiej. Dołączone regulacje odnosiły się m.in. do kwestii przygotowania narodowego stanowiska negocjacyjnego.

Artykuł 59 a Aktu Autonomii stanowi, iż rząd alandzki może uczestniczyć wspólnie z rządem Finlandii w przygotowaniu stanowiska negocjacyjnego odnośnie decyzji podejmowanych w Unii Europejskiej, jeżeli sprawa znajduje się w kompetencjach Alandczyków, bądź ma szczególne znaczenie dla Wysp. Jeżeli stanowisko władz Wysp różni się w znaczący sposób od stanowiska rządu Finlandii, to stanowisko strony alandzkiej przedstawiane jest obok oficjalnego stanowiska strony fińskiej. Artykuł 59 a ust. 2 Aktu Autonomii stanowi, iż w sytuacji, gdy decyzja Unii Europejskiej w całości bądź w części dotyczy zastosowania polityki wspólnotowej na Wyspach Alandzkich, rząd alandzki formułuje stanowisko Finlandii w zakresie odpowiadającym kompetencjom Wysp. Rząd alandzki informowany jest o przygotowaniach do podjęcia decyzji w Unii Europejskiej.

Artykuł 59 b Aktu Autonomii stanowi, iż w procesie implementacji decyzji podjętych przez Unię Europejską, kompetencje ustawodawcze i wykonawcze podzielone są pomiędzy stronę alandzką oraz stronę fińską. W sytuacji, gdy brak jest zgody co do form i środków implementacji decyzji Unii Europejskiej, delegacja alandzka może rekomendować jej odrzucenie. Artykuł 59 b ust. 4 Aktu Autonomii stwierdza również, iż rząd Wysp Alandzkich może kontaktować się z Komisją Unii Europejskiej $\mathrm{w}$ sprawach leżących w kompetencjach autonomii i związanych $\mathrm{z}$ implementacją decyzji Unii Europejskiej na Wyspach. Rząd alandzki uzgadnia wspólnie z rządem Finlandii sposób przekazywania informacji o szczegółach tych kontaktów.

Kwestia udziału Wysp Alandzkich w odpowiedzialności finansowej Finlandii uregulowana jest w artykule 59 d Aktu Autonomii. Jeżeli zatem Trybunał Sprawiedliwości Unii Europejskiej nałoży na Finlandię obowiązek wypłaty odszkodowania, grzywnę warunkową bądź inną porównywalną sankcję finansową, Wyspy Alandzkie podlegają danej karze solidarnie wraz z Finlandią w wysokości wynikającej z działań lub zaniechań Alandów. Jeżeli natomiast Finlandia zmuszona jest do zwrotu funduszy Unii Europejskiej, Wyspy Alandzkie zobowiązane są do wspólnego zwrotu funduszy w części, w której zarządzanie lub kontrola nad nimi należała do ich kompetencji.

referendum przeprowadzonym na Wyspach Alandzkich 20 listopada 1994 r. większość mieszkańców prowincji opowiedziała się za członkowstwem w Unii (blisko 74\%). Również parlament Wysp (Lagting) przegłosował kwestię przystąpienia do unijnych struktur. Głosowanie w parlamencie alandzkim odnośnie przystąpienia do Unii Europejskiej odbyło się 2 grudnia 1994 r., za przystąpieniem opowiedziało się 26 parlamentarzystów przy 4 głosach przeciwnych. 
Natomiast w sytuacji, gdy Finlandia zobowiązana jest do wypłaty odszkodowania za szkody wynikłe z niepełnej lub nieodpowiedniej implementacji prawa wspólnotowego w sprawach leżących w kompetencjach Wysp, strona alandzka zobowiązana jest do wypłacenia odszkodowania solidarnie ze stroną fińską ${ }^{44}$.

Powszechnie wiadomo, iż w Unii Europejskiej decyzje podejmowane są przez państwa członkowskie. Jedynie reprezentanci państw czosnowskich Unii uprawnieni są do udziału w głosowaniach w unijnej Radzie Ministrów. Autonomiczne terytoria należące do unijnych państw członkowskich nie mają prawa do udziału w głosowaniach w Radzie. Jedynym sposobem wywierania wpływu na procesy decyzyjne przez terytoria autonomiczne jest oddziaływanie na reprezentację państwa członkowskiego, do którego należy dany region autonomiczny. Autonomia alandzka posiada jednak możliwość wywierania wpływu na proces decyzyjny w Unii na dwóch poziomach. Na pierwszym poziomie strona alandzka może wpływać na proces formułowania stanowiska Finlandii w unijnej Radzie Ministrów. Natomiast na drugim poziomie strona alandzka prezentuje swoje stanowisko samodzielnie na arenie międzynarodowej. Alandczycy nie mają jednak swoich przedstawicieli ani w Parlamencie Europejskim, ani w unijnej Radzie Ministrów. Wyspiarze mogą zatem wywierać jedynie pośredni wpływ na obie instytucje.

Byłoby jednak nadużyciem stwierdzenie, iż Alandczycy pozbawieni są zupełnie własnych przedstawicieli w Brukseli. Poza nieoficjalnym kanałem prezentowania kwestii o wymiarze regionalnym, istnieje również instytucja Komitetu Regionów Unii Europejskiej. Kwestię tę dokładnie reguluje artykuł 59 e Aktu Autonomii stanowiący, iż osoba desygnowana przez rząd alandzki jest jednym z przedstawicieli Finlandii w unijnym Komitecie Regionów. Komitet jest organem konsultacyjnym, reprezentującym na arenie Unii Europejskiej różne interesy regionalne. Komitet Regionów jest również organem doradczym Rady i Komisji Unii Europejskiej. Zarówno Rada, jak i Komisja zobowiązane są do zasięgnięcia opinii Komitetu. Instytucja Komitetu Regionów może również z własnej inicjatywy przedkładać tym organom swoje opinie. Również Parlament Europejski może zasięgnąć opinii Komitetu ${ }^{45}$. Należy przy tym wspomnieć, iż przy stałej misji fińskiej w Brukseli miejsce posiada także komisarz ds. informacji w kwestiach dotyczących Wysp Alandzkich. Komisarz ten informuje rząd alandzki o działalności instytucji Unii Europejskiej. Do jego zadań należy również informowanie instytucji unijnych o sytuacji w autonomii alandzkiej.

\footnotetext{
44 Åland in the European Union, op.cit., s. 22.

${ }^{45}$ Z.M. Doliwa-Klepacki, Integracja Europejska, Wyd. Temida 2, Białystok 2005, s. 423.
} 


\section{Sprawy unijne w parlamencie alandzkim}

Udział $\mathrm{w}$ procesie przygotowania wspólnego stanowiska negocjacyjnego jest wyjątkowo ważny dla strony alandzkiej. Wynika to $\mathrm{z}$ faktu, że po przystąpieniu Finlandii do Unii Europejskiej decyzje należące niegdyś do wyłącznej kompetencji Alandczyków zostały przekazane Unii. W sytuacji, gdy Komisja Europejska przedstawia propozycje nowych uregulowań prawnych danej kwestii, państwa członkowskie przygotowują stanowiska negocjacyjne w obrębie własnych delegacji. Jak wspomniano powyżej, strona alandzka może wyrazić swoją opinię podczas procesu formułowania stanowiska strony fińskiej. Opinia autonomii alandzkiej formułowana jest przez rząd Wysp bądź przez parlament alandzki. Rząd alandzki bierze zatem udział w procesie formułowania stanowiska rządu Finlandii w sytuacji, gdy omawiana kwestia ma szczególne znaczenie dla Alandów, bądź znajduje się w zakresie kompetencji strony alandzkiej.

Rząd alandzki informuje parlament Wysp o istotnych dla autonomii kwestiach bezpośrednio dotyczących Unii. W sprawach „unijnych” rząd posiada dwie możliwości kontaktowania się z parlamentem. Pierwsza polega na przekazaniu parlamentowi noty, która omawiana jest przezeń na sesji plenarnej. Procedura ta wykorzystywana jest szczególnie w przypadku prowadzenia międzyrządowych konferencji. Istnieje również procedura wspólnych konsultacji parlamentarno-rządowych, których przedmiotem są kwestie odnoszące się do Unii Europejskiej. Jeśli nie ma możliwości odbycia wspólnych konsultacji, parlament otrzymuje zwykłą informację o danej kwestii.

Zarówno rząd Finlandii, jak i strona alandzka przygotowują swoje stanowiska w kwestiach związanych z Unią. Stanowisko strony fińskiej koordynowane i uzgadniane jest przez szereg komitetów pomocniczych, przy czym każde ministerstwo desygnuje urzędnika ds. autonomii alandzkiej. Ponadto strona alandzka posiada swoich reprezentantów we wszystkich komitetach pomocniczych. Komitety te zobowiązane są do informowania rządu alandzkiego o wszystkich istotnych dla Wysp kwestiach dotyczących Unii. Komitety pomocnicze przedstawiają daną kwestię Komisji do spraw Unii Europejskiej. W komisji tej zasiada przedstawiciel rządu alandzkiego, który posiada prawo głosu w kwestiach dotyczących Wysp. Na płaszczyźnie unijnej strona alandzka, po uprzednim złożeniu wniosku, może brać udział w pracach delegacji fińskiej w Radzie Europejskiej oraz w jej grupach roboczych.

Autonomia alandzka zachowała kompetencje ustawodawcze wykonywane na terenie prowincji. Jednocześnie władze Autonomii zobowiązane są do przeprowadzania harmonizacji i dostosowywania regulacji prawnych prowincji do ustawo- 
dawstwa unijnego ${ }^{46}$. Należy podkreślić, iż w powszechnej opinii przystąpienie Finlandii do Unii Europejskiej, a w efekcie czego również i Wysp Alandzkich, przyczyniło się do zwiększenia kontaktów na szczeblu rządowym pomiędzy autonomią a fińską macierzą.

Powszechnie znana jest niechęć obywateli państw członkowskich Unii do jej nadmiernej biurokracji i przepaści pomiędzy codziennym życiem obywateli, a działalnością unijnych instytucji. Alandczycy nie są w tym względzie wyjątkiem. Mimo poparcia akcesji prowincji do Wspólnoty w 1994 r. w referendum zarówno ogólnokrajowym, jak i tym przeprowadzanym jedynie na terytorium prowincji ${ }^{47}$, na bardzo niskim poziomie utrzymuje się frekwencja wyborcza w wyborach do Parlamentu Europejskiego. Dobitnym tego przykładem jest jedynie 21-procentowa frekwencja wyborcza w wyborach do Parlamentu Europejskiego w 1999 roku$^{48}$. W 2004 r., również w wyborach do parlamentu Europejskiego, frekwencja wynosiła już 36\%, co było najprawdopodobniej podyktowane faktem startowania w wyborach dwóch kandydatów z Wysp ${ }^{49}$. Z przeprowadzonych badań opinii publicznej wynika, że Alandczycy są bardziej krytycznie nastawieni do Unii niż ich fińscy sąsiedzi.

Wyspy Alandzkie, jako autonomiczna część Finlandii, są z mocy prawa członkiem wszystkich organizacji międzynarodowych (choć w niektórych organizacjach międzynarodowych Alandy stanowią odrębny podmiot polityczny), do których przystąpili ich fińscy pobratymcy. Wraz z przystąpieniem Finlandii do Rady Europy w 1989 r., przystąpiła do tej organizacji również autonomia alandzka. Alandy od 1957 r. jako część Finlandii są członkiem Rady Nordyckiej, a od 1970 r. mają status odrębnego podmiotu w tej organizacji. W 1984 r. prowincja została członkiem Nordyckiej Rady Ministrów.

Wynik negocjacji akcesyjnych prowadzonych z Unią Europejską oraz ostateczne przystąpienie Wysp do struktury Wspólnoty w powszechnej opinii odebrane zostało jako sukces autonomii. Wejście Alandów do strefy euro w 2002 r. odczytać należy jako znaczący akt integracji ze strukturami unijnymi.

46 Aland in the European Union, op.cit., s. 28.

${ }^{47}$ Należy tu jednak podkreślić, iż w momencie przeprowadzania referendum na terenie prowincji wiadome już było, że zarówno Finlandia, jak i Szwecja przystąpią do Unii Europejskiej.

${ }^{48}$ Niska frekwencja w wyborach do Parlamentu Europejskiego w 1999 r. była zaskoczeniem również dlatego, że startowała w nich kandydatka Szwedzkiej Partii Pracy, Astrid Thors, ciesząca się na Wyspach powszechnym poparciem.

${ }^{49}$ Ze względu na to, iż Alandy nie mają własnego reprezentanta w Parlamencie Europejskim, dwoje kandydatów z Wysp Alandzkich - Viveka Eriksson oraz Barbro Sundback - kandydowało z ogólnonarodowych list wyborczych. 
Należy jednak podkreślić, iż wciąż część ludności Alandów wysuwa postulaty zwiększenia niezależności od rządu centralnego w Helsinkach i przyznania prowincji m.in. prawa do wybierania własnego przedstawiciela do Parlamentu Europejskiego. Postulaty Alandczyków nie mają jednak charakteru separatystycznego, ich cel odnosi się jedynie do szerszego zakresu autonomii. Słusznie zauważa M. Sobczyński, że mimo, iż pozycja archipelagu alandzkiego na arenie międzynarodowej nie satysfakcjonuje w pełni władz prowincji, to nie zdecydowały się one, jak dotąd, przystąpić do Organizacji Narodów i Ludów Niereprezentowanych (Unrepresented Nations and Peoples Organisation, UNPO) zrzeszającej regiony niezadowolone ze swego statusu oraz sytuacji politycznej.

Widoczna i wyraźna przewaga czynnika szwedzkiego w postaci przewagi szwedzkojęzycznej ludności oraz szwedzkiego kręgu kulturowego nie destabilizuje równowagi w prowincji. Sama strona szwedzka również nie wysuwa żadnych postulatów rewizji ustaleń międzynarodowych odnośnie statusu Wysp ${ }^{50}$. Należy przy tym wspomnieć o ukształtowaniu się wyraźnej tożsamości narodowo-regionalnej Alandczyków broniących i manifestujących od lat swoją autonomiczność.

Strategiczne z polityczno-militarnego punktu widzenia położenie Wysp Alandzkich sprawiło, iż stały się one w przeszłości przedmiotem wielu sporów i konfliktów prowadzonych o hegemonię w regionie Morza Bałtyckiego. Wydarzenia te wywarły wpływ na losy Alandów. Przeważająca część doktryny wyraża opinię, iż zarówno konwencja o demilitaryzacji i neutralizacji Alandów z 1921 r., jak również dwustronna umowa między Finlandią i Związkiem Radzieckim z 1940 r. oraz Paryski Układ Pokojowy z 1947 r. zachowują nadal moc prawną.

Neutralizację oraz demilitaryzację regionu Alandów uznać należy jako ważne elementy uregulowania ich statusu. Zdemilitaryzowany i zneutralizowany status Wysp stał się jednym z czynników stabilizujących i zapewniających równowagę w basenie Morza Bałtyckiego.

W czasie negocjacji akcesyjnych prowadzonych przez Finlandię z Unią Europejską Komisja unijna potwierdziła zdemilitaryzowany status archipelagu alandzkiego. Protokół nr 2 (Protokół Alandzki - aneks do traktatu akcesyjnego Finlandii do Unii Europejskiej) uznaje w preambule szczególny status Alandów w prawie międzynarodowym.

Sądzę, iż jest wysoce prawdopodobne, że kwestia demilitaryzacji i denaturalizacji regionu powróci na arenę międzynarodową w kontekście debaty odnośnie ewentualnego przystąpienia Finlandii do struktury Organizacji Paktu Północnoatlantyckiego.

\footnotetext{
${ }^{50}$ K. Dośpiał-Borysiak, Państwa nordyckie a Unia Europejska, Wyd. Sejmowe, Warszawa 2007, s. 51.
} 
Wydaje się $\mathrm{w}$ pełni zasadne stwierdzenie, iż $\mathrm{w}$ interesie wszystkich państw Regionu Bałtyckiego, jak również pozostałej części wspólnoty międzynarodowej, leży utrzymanie obecnego statusu Wysp Alandzkich. Status prowincji stał się w pewnym sensie zwyczajem międzynarodowym, respektowanym nieprzerwanie od końca II wojny światowej przez wszystkie państwa regionu. Zarówno zdemilitaryzowany, jak również zneutralizowany status ważnego strategicznie obszaru, będącego w przeszłości wielokrotnie przedmiotem sporu, sprzyja utrzymaniu stabilności i bezpieczeństwa w regionie.

Członkostwo Alandów w strukturach organizacji międzynarodowych o charakterze regionalnym - ogólnonordyckim (Rada Nordycka, Nordycka Rada Ministrów), jak również w strukturach organizacyjnych o charakterze ogólnoeuropejskim (Unia Europejska, Rada Europy), potwierdza ambicje regionu do pełnego i aktywnego uczestnictwa prowincji w społeczności międzynarodowej.

\section{The Åland Islands in International Law. The demilitarized and neutralized status of the Åland Islands}

This article deals with the question of demilitarization and neutralization of the Åland Islands in respect to international law regulating this issue. In this paper it was not intented to go into details of all historical phases and changes of the Åland's status, but rather to concentrate on international treaties regulating this question, which are still in force.

Åland is an autonomous, demilitarized and neutralized region of Finland with a largely Swedish-speaking population. The Åland Islands form an archipelago in the Baltic Sea. They are situated in the entrance to the Gulf of Bothnia. Its legislative autonomy and a strong protection for its population's Swedish language and culture are enshrined in the Finnish constitution. The Åland Islands are located in a very strategically important place.

There are three problems under international law connected with the Åland Islands: that is to say, demilitarization, neutralization and autonomy of Åland. After the Crimean war it was decided that Russia should not fortify the Åland Islands. The strategic position was one of the factors that influenced the decision of the Paris Peace Conference in 1856 to demilitarize the Åland Islands. After the Crimean War (1854-56) an appendix to the 1856 Treaty of Paris forbade Russia from establishing fortifications, maintaining or building up a military presence and naval forces on the islands. In 1917 Finland gained independence from Russia and Åland became for a number of years a source of controversy or even conflict 
between Finland and Sweden as a result of the Ålanders' demand for Åland's reunification with Sweden. In 1921 the League of Nations resolved the Åland question. Åland remained a part of Finland but gained autonomy along with the historically rooted principles of neutrality and demilitarization. In October 1921 the Convention relating to the non-fortification and Neutralization of the Åland Islands was signed by Denmark, Estonia, Finland, France, Germany, Italy, Latvia, Poland, Sweden and the United Kingdom. The Western powers did not regard Bolshevik Russia as a sovereign state after the revolution of 1917 and Russia (the Soviet Union) was not a party to this convention. The treaties that regulatedthe demilitarization and neutralization were: 1 ) the 1856 Convention on the Demilitarisation of the Åland Islands (annexed to the 1856 Paris Peace Treaty), 2) the 1921 Convention on the Demilitarization and Neutralization of the Åland Islands, 3) bilateral treaty of 1940 between Finland and Russia (the Soviet Union) on the demilitarization of the Åland Islands and 4) the 1947 Paris Peace Treaty.

There is no cause to doubt the continuance in force of the demilitarization and neutralization of Åland. The treaties and agreements of 1921,1940 and 1947 are still in force. Åland's demilitarization and neutralization remain beyond question, despite the changes in the political context.

The Åland Islands are both demilitarized and neutralized, the main purpose is to keep it completely outside the armed actions of armed conflicts.

Åland's status received renewed attention in the 1990s in view of the changes taking place in Europe. The 1994 treaty on Finland's accession to the EU recognizes in its Protocol No. 2, that the Åland Islands enjoy a special status under international law. Furthermore, another legal regulation dealing with this question is the Additional Protocol I to the 1949 Geneva Convention on the protection of war victims (Article 60) obligates States Parties to respect demilitarized zones during international armed conflicts. Åland's demilitarized and neutralized status has a strong foundation and position in the international law. Some experts and writers have described this status as a example of a "permanent settlement" or "objective regime" in international law. According to another experts (H. Rotkirch), the special status of the Åland Islands is of such long standing "that it has without doubt become part of customary international law and is thus binding on the international community as a whole". Since 1970, Åland has had its own representation in the Nordic Council and participates in the work of the Nordic Council of Ministers. Since 1989, Åland is a member of the Council of Europe. One might also mention the fact that, Åland stands outside the EU tax union and has retained the limitations on ownership of land and operation of business. 


\section{Le problème des îles d'Åland en droit international. Le statut de démilitarisation et de neutralisation des Îles d'Åland}

Larticle traite de la question de la démilitarisation et de la neutralisation des Îles d'Åland en ce qui concerne le droit international régissant cette question. Dans cette étude, mon intention n'était pas de rentrer dans les détails de toutes les phases historiques et de tous les changements de statut des îles d'Åland, mais plutôt de se concentrer sur les traités internationaux régissant ce problème, qui sont toujours en vigueur.

Åland est une région autonome, démilitarisée et neutralisée de la Finlande dont la population est majoritairement de langue suédoise. Les Îles d’Åland forment un archipel dans la mer Baltique. Elles sont situées à l'entrée du golfe de Botnie, dans un lieu stratégiquement très important. Leur autonomie législative et leur forte protection de la langue sudeoise et de la culture de leur population sont inscrites dans la Constitution finlandaise.

Il y a trois problèmes au regard du droit international en rapport avec les Îles d’Åland: c'est-à-dire, la démilitarisation, la neutralisation et l'autonomie. Après la guerre de Crimée il a été décidé que la Russie ne devrait pas fortifier les îles d'Åland. La position stratégique a été l'un des facteurs qui ont influencé la décision de la Conférence de paix de Paris en 1856 de démilitariser ces îles. Après la guerre de Crimée (1854-56) une annexe au traité de Paris de 1856 a interdit à la Russie d'établir des fortifications, de maintenir ou de construire une présence militaire et des forces navales sur les îles.

En 1917, la Finlande a obtenu son indépendance de la Russie. Les Îles d’Åland sont devenues pour un certain nombre d'années un objet de la controverse ou même du conflit entre la Finlande et la Suède à la suite de la demande ålandaise de réunifier des Îles d’Åland avec la Suède. En 1921, la Société des Nations a résolu la question des Îles d'Åland. Elles sont restées une partie de la Finlande, mais elles ont acquis leur autonomie ainsi que les principes historiques de neutralité et de démilitarisation. En octobre 1921, la Convention relative à la non-fortification et à la neutralisation des Îles d'Åland a été signée par le Danemark, l'Estonie, la Finlande, la France, l'Allemagne, l'Italie, la Lettonie, la Pologne, la Suède et le Royaume-Uni. Puisque les puissances occidentales n'ont pas considéré la Russie bolchevique comme un État souverain après la révolution de 1917, l'URSS ne faisait pas partie de la convention. Les traités qui régissent la démilitarisation et la neutralisation comprennent: 1) la Convention relative à la démilitarisation des Îles d'Åland de 1856 (annexé au traité de paix de Paris 1856), 2) la Convention sur la démilitarisation et la neutralisation des Îles d’Åland de 1921,3) le traité bilateral 
entre la Finlande et la Russie (l'URSS) sur la démilitarisation Îles d'Åland de 1940 et 4) le Traité de paix de Paris de 1947. Les traités et accords de 1921, 1940 et 1947 sont toujours en vigueur. Malgré les changements dans la situation politique, la démilitarisation et la neutralisation des Îles d'Åland ne peuvent pas être remises en questions.

À l'occasion des changements en Europe dans les années 1990, la question du statut des Îles d'Åland est réapparue. Le traité sur l'adhésion de la Finlande à l'UE de 1994 reconnaît dans son Protocole ${ }^{\circ}{ }^{\circ}$ 2, que les Îles d'Åland jouissent d'un statut spécial en vertu du droit international. En outre, une autre réglementation juridique traitant de cette question est le Protocole additionnel I à la Convention de Genève de 1949 pour la protection des victimes de la guerre (article 60). Il impose aux États parties l'obligation de respecter les zones démilitarisées pendant les conflits armés internationaux.

Le statut des îles a une base solide en droit international. Certains experts et écrivains ont décrit ce statut comme un exemple d'un «règlement définitif» ou d'un «régime objectif» en droit international. Selon un autre expert (H. Rotkirch), le statut particulier des Îles d'Åland «est devenu sans aucun doute partie du droit international coutumier et il s'impose à la communauté internationale». Depuis 1970, les Îles d'Åland ont leur propre représentation au sein du Conseil nordique et participent aux travaux du Conseil nordique des ministres. Depuis 1989, les Îles d'Åland sont membre du Conseil de l'Europe. On pourrait aussi mentionner le fait qu'elles sont hors de l'union fiscale de l'UE et elles ont retenu les restrictions sur la propriété de la terre et sur le fonctionnement des entreprises. 